\title{
INDONESIAN-PHILIPPINE CO-PRODUCTION MOVIE: FROM RODRIGO DE VILLA TO HOLIDAY IN BALI
}

\author{
J.E. Luik \\ Jurusan Ilmu Komunikasi, Fakultas Ilmu Komunikasi \\ Jalan Siwalankerto 121-131 Surabaya, 60236 \\ Email: jandyluik@peter.petra.ac.id
}

\begin{abstract}
The movie industries in Indonesia and the Philippines were facing similar challenge during World War II period. Consequently, post-War period became the period of re-settlement the movie industry with certain efforts. Despite the internal development, expanded the cooperation to the neighbor countries was chosen to strengthen the movie industry. Pioneered by Persari and LVN Pictures, the cooperation expanded to the co-production. The historical literatures and interview to one of the people involved gives the perspective about the cooperation between Indonesia and the Philippine
\end{abstract}

Keywords: Philppines Movie, Indonesian Movie, Co-production Movie, Rodrigo de Villa, Holiday in Bali.

\section{INTRODUCTION}

The Indonesian and Philippine movie industries were in a difficult situation during World War II period. The colonizers limited the film industries to the production of propaganda. Only a few theaters and studios were allowed to run. To make it worse, most of film facilities in both countries were destroyed during the war period. After 1945, companies in the Philippines rebuilt their facilities immediately. On the contrary, Indonesia was still focusing on defending its Independence until the end of 1949 .

After the Indonesian revolution era in the 1950s, the problems faced by Indonesian moviemakers involved the availability of equipment and technology. It was not easy to develop the Indonesian movie industry considering the limitations of technology and the abundance of imported movies. Various efforts to attract movie viewers should not only focus on maximizing movie industry internal potentiality, but also getting inspiration or new ideas from others. One of the efforts done by Indonesian movie practitioners was producing movies with a studio from the Philippines.

The initial history of cooperation between Indonesia and the Philippines in movie production can be traced back even before the co-production. Persari used to develop its movies in the laboratory of LVN Pictures. The cooperation started with productions of two version movies and then grew to one. The two versions are the ones produced in Indonesian and Philippine versions in which the actors and actresses are different. While in the one version, the actors and actresses from both countries played together in the movie as seen in the cooperation between Persari and Sampaguita Pictures Inc. 
Therefore, the aim of this paper is to describe a history of Indonesian-Philippine coproduction movie. The writer explored related literature and interviewed co-director of Holiday in Bali.

\section{DISCUSSION}

\section{Indonesian and Philippine Movie in early 1950's}

Indonesian film making in the early 1950s was infiltrated by nationalism, the main issue at that time. After the revolutionary war, Indonesians had the passion to build and maximize their own potential in every part of nation including through movie making. Limited movie technology did not hamper the establishment of Indonesian Film Companies. Perfini, founded by Usmar Ismail, and Persari, founded by Djamaludin Malik, were established to encourage the national movie development. The number of films produced increased from 24 in 1950 up to 40 in 1951 and the number of people involved in moviemaking increased. Due to limited technology of that time, the movies were in black-and-white.

"Despite the influx of workers, skills didn't improve and many of the films that were subsequently produced were of poor quality. By 1950, moviegoers began to tire of local films. The press began to be highly critical, too" (Suwardi 25). Ironically, in this positive atmosphere, there were opposite responses from the public about Indonesian movies. The quality of some movies was poor and it was not only caused by technical reasons but also the story itself. To make it worse, the abundance of foreign films form America, the Philippines, and India forced most of Indonesian movies to be shown in second-class theaters. Even, in those theaters, Indonesian movies had to compete with India's movies.

In the Philippines, the early 1950s was the beginning of the Philippines' movie Golden Age. Movie production was dominated by the Big Three: LVN Pictures known for comedies and musicals, Sampaguita Pictures for melodramas, and Premiere for action movies (Del Mundo 96). At that time, Philippine studios were already equipped with modern technology to produce color movies. This facility certainly enhanced the quality of the movie produced. LVN studio, for example, had a good quality studio equipped for color movie productions. Furthermore, the Philippines' movie golden age was also signaled by the increasing appreciation of its movies through a number of awards, starting with the Maria Clara Awards to the Filipino Academy of Movie Arts and Sciences (FAMAS) Awards.

LVN and Sampaguita Pictures have taken share in movie award on Maria Clara and FAMAS in early 1950's. In the first Maria Clara Awards in 1950, LVN received awards for their people: Dona Sisang received the award for best producer and Tony Santos won the best supporting award, while Sampaguita received award in best cinematography and best supporting actress. In 1951 Maria Clara Awards, Sampaguita's people received best director award, best child actress, best supporting actress, cinematography, and producer of the year by Judge Jose O. Vera. Awards in movie become FAMAS Awards 1952 and both film studios' people continue to taken part on winning the awards.

After the Indonesian revolution in the 1950s, Indonesian moviemakers faced some problems in equipment and technology, while the Philippine studios had 
advanced technologically. Realizing this condition, Indonesian film companies proposed a form of cooperation with the Philippines' studios.

\section{2: Beginning of Indonesian - Philippine co-production}

As stated before, one of the problems in Indonesia was its movie technology, especially in terms of laboratory. Addressing that problem, Persari decided to develop a film with a Philippine studio, LVN led by Dońa Sisang. LVN was also chosen by Djamaludin Malik as a consultant to found Persari laboratory because at that time the laboratory was considered to possess high technology applications in South East Asia Region.

After the founding of the laboratory, Persari sent some of their movie creators to learn about movie making in the Philippines. Then, the cooperation was continued to produce movies (Yusa Biran).

The first co-production movie between Indonesia and the Philippines was Rodrigo de Villa in 1952 (Kristanto 23, Tiongson 300). Persari and LVN were two companies working together to make this Ansco color movie. It was the first color movie for Indonesia, while for the Philippines, this was the first co-production movie with a foreign film company.

Rodrigo de Villa was produced in two versions, the Philippines and Indonesian ones. Rempo Urip directed the Indonesian version, while Gregorio Fernandez directed the Philippine version. The story was written by Nemesio Caravana, in Liwayway.

Rodrigo de Villa is a story similar to the Middle-Age battle. The battle in this movie starts with invasion of Turkey to the Castile. Isabella (Queen of Castile) and Lozano (nobility) betray King Alfonso and decide to help Turkey. Attacked from the external and internal sides, King Alfonso and Rodrigo (loyal swordsman) are arrested, while Lozano and Isabella become the king and queen of Castile. Finally, Rodrigo and Alfonso are released by Selima (daughter of Turkey's leader) and together with Rodrigo's brother, they defeat King Lozano and expel Turkey's army. A love story is included in this power struggle movie (Kristanto 23)

Unfortunately, the similarity of this sword movie's story with the second-class studio movies caused a negative response from the public. In the post-revolution war, the people were yearning for innovation and this movie seemed to represent the opposite way.

In 1953, Persari and VLN continued to make the next co-production movie entitled Leilani (Tabu). This is the second color movie in Ansco color for Persari and the director of this movie is Rempo Urip. The story is about the effort of a new marriedcouple to get together after separated by storm in the ocean. They travel by a ship in the Pacific Ocean and ashore in different island to maintain their love. Leilani was made in Indonesian version with local actors and actresses (Kristanto 28).

Ten years after the first movie, Djamaludin Malik continued to make another coproduction movie. Sampaguita Pictures Inc. and Persari worked together to produce Holiday in Bali.

\section{2: Holiday in Bali}

In 1962, Persari brought some of Sampaguita's stars and director to make a film in Bali (Indonesia). Tony Cayado and Misbach Yusa Biran directed Holiday in Bali. 
Holiday in Bali was produced in one version with English language, and Indonesian and Philippines actors and actresses playing in the same movie. Luis Gonzales, Josephine Estrada, and Daisy Romualdez came to Bali and joined with Chitra Dewi, Johny Misa, and Jusman to play their characters.

The film is about a complicated love story between a Filipino and a Balinese woman and used some tourist destination in Indonesia. Luciana Carlos started the story with the encounter between Cokorde Gede Rai (Johny Misa), who is studying in the Philippines, and Angelo Reyes (Luis Gonzales), the botanist. Reyes decides to research about plants in Bali, but before he arrives in Bali, Cokorde accompanies him to see some tourist spots Borobudur, Buddhist's temple. While conducting his research, Reyes falls in love with a Balinese girl, Aryani (Josephine Estrada). Aryani is a sister of Suryati (Chitra Dewi), Cokorde's lover. Problem happens when Reyes' lover, Liza (Daisy Romualdez), comes to Bali and knows that Reyes is falling in love with Aryani. Liza tries to stop his lover relation but she fails, Reyes and Aryani become lovers. Finally, Liza has a new lover, Raka (Jusman) who fails to marry Aryani (Kristanto 62).

Technically, there was no significant constraint in terms of shooting time. Difficulty in the making was coming from the producer viewpoint is related to the marketing. The main difficulties were from the producer who wanted to mainly display the scenes that have selling power even though they conflicted with esthetics and ethics. For instance, the Philippines' producers preferred to modify the scenes to be more stylish which was not common in Balinese culture. For instance, the producer wanted to modify the scene of walking girls on the side of the street by adding a conversation between lovers. Originally, in the Balinese culture, there was no activity like that.

Since this is a co-production, problems should be discussed together. Tony Cayado was the leading director and Misbach Yusa Biran was the co-director. Both of them support each other by giving ideas or corrections. They always had discussion before they decided to take pictures. Regarding the modified scene, both directors and screenwriter discussed it and Tony Cayado decided to obey Balinese culture. Stagnation in this movie making was avoided because of full understanding from Tony Cayado and support from Misbach Yusa Biran.

During its premier show, there was a slight doubt that the movie would be successful among the moviegoers. It happened because of the abundance of foreign movies especially from India and America, and the falling number of Indonesian movies from 37 (1961) to 15 (1962) were challenging the Holiday in Bali's circulation. Political condition in Indonesia, with the rise of Communist party and anti-foreign products, would have been an obstacle for the movie. Fortunately, this condition did not bring any negative response because the story is sensible and in accordance with Indonesian culture.

The movie's marketing in Indonesia was not very successful because the economic condition at that time was not so good and the inflation rate was high. It gave significant effect on the Indonesian public's purchasing power, which was low causing the movie to be circulated moderately. However, in the international level Holiday in Bali received a special award in the 1963 Asian Film Festival in Tokyo. 


\section{CONCLUSION}

It seems difficult to assess the significance of Holiday in Bali to IndonesianPhilippine co-production because there is no longer of co-production until today. As mentioned above, cooperation with foreign moviemakers was one of the efforts to search the way out from movie stagnation in Indonesia. After the recovery from the condition, it seems that the urgency of such cooperation becomes less and even stopped. Specifically, transfer technology in movie had been done. As the consequence, Holiday in Bali becomes the end of a co-production driven by technological transfer.

Regarding the discontinuity of co-production, external factor as condition of countries should by considered. After Holiday in Bali, Indonesia was entering a complicated political situation. Moreover, this condition had happened before and it spread to other areas such as economy and social welfare. One of the current issues at that time is anti-foreign sentiment, especially America, limited the relations between Indonesians and foreigners. This negative trend affected Indonesian movie and especially co-production with the Philippine.

In spite of discontinuity, co-production between Indonesian and the Philippines brings advantages to both countries. The significance of the co-production can be seen from these three movies, namely Rodrigo de Villa (Persari-LVN ), Leilani (PersariLVN), and Holiday in Bali (Persari-Sampaguita). The significance of co-production to Indonesia can be founded in the increase of knowledge and movie technology. Philippine studios contributed to the emergence of color movie in Indonesia. As mentioned, the Persari film laboratory was advised by LVN and the first Indonesian color movie resulted from this co-production. For the Philippines, co-production with Indonesia can be understood as a chance for sharing experience because during that period Philippines movie industry was considered advanced in South-East Asia. A large number of Philippine's movies was exported to several countries including Indonesia. Certainly, this condition made the Philippine as a place for inspiration and innovation in movie making in the South-East Asian region.

\section{REFERENCES}

Constantino, R.K, \& Lo. Richard F. The Golden Years Memorable Tagalog_Movie Ads 1946 - 1956. Manila: Danny Dolor, 1994.

Del Mundo, Clodualdo Jr. "Philippines". The Films of ASEAN. Ed. Jose F. Lacaba. Quezon City: ASEAN Committee on Culture and Information, 2000.

Kristanto, J.B. Katalog Film Indonesia 1926 - 2005. Jakarta: Nalar, 2005.

Suwardi, Harun. "Indonesia". The Films of ASEAN. Ed. Jose F. Lacaba. Quezon City: ASEAN Committee on Culture and Information, 2000.

Tiongson, Nicanor G., ed. CCP Encyclopedia of Philippine Art: Philippine Film. Vol 8. Manila: Cultural Center of the Philippines, 1994.

Yusa Biran, Misbach H. E-mail to the author. 28 Jul. 2007

Email to the author. 4 Aug. 2007 